\title{
On Status Quo and Choices of Development Paths of County-level Community Banks
}

\author{
Liang-Xin Li \\ Hunan International Economics University \\ Business School \\ Changsha, Hunan, China
}

\author{
Lu Wang \\ Hunan International Economics University \\ Business School \\ Changsha, Hunan, China
}

\begin{abstract}
Through investigate on different financial development at home and abroad, it is found that a sound and complete financial system is a common practice which includes large commercial banks, small and medium-sized banks, and various types of bank financial institutions. Only in this way can the entire level of the financial system be enriched and Systemic financial system risk can be reduced. This article first explains the definition of community banks, then analyzes the characteristics of county-level community banks from the facts of county-level community banks in China's joint-stock banks and city commercial banks, and then analyzes their development status. Secondly, the development model and experiences of foreign community banks are used for reference. Also, the development model of community banking in county districts in China is analyzed with the example of Qingdao Jiaonan Haihui Village Bank, Minsheng Bank and Guangfa Bank Community Bank. Thirdly, through the analysis of the status quo, it is pointed out that county-level community banks in China have blind expansion of outlets, is lack of diversity and innovation in financial services and products, is short of target customers in county-level community banks, and is full of unsound customer experience and feedback systems. Finally, based on the deficiency fact of county-level community banks, the author puts forward the development path choices of county-level community banks in China.
\end{abstract}

Keywords-community banks; county economy; development model; path selection

\section{INTRODUCTION}

\section{A. Overview}

County economy is the most basic part of the national economy and a combination of macro economy and micro economy. Here, the county economy refers to an open, fully functional, regional economy with regional characteristics in the county or the urban community to arrange and optimize the economic and social resources. Because of the characteristics of county economy, it plays a very important role in China's social economy. The development of the county economy is an important way to increase the income of the peasants; it is an important guarantee for the prosperity of the rural economy; the county economy is an important basis for the development of small towns. The rapid development of financial industry is conducive to the rapid development of county economy in China. At present, the financial support of "three rural" and small and medium-sized enterprises has become a restriction on the rapid economic development of our country. In order to realize the deep development of the socialist market economy in China, the bottleneck of the development of the county economy must be solved.

\section{B. Research Trends at Home and Abroad}

\section{1) Foreign research trends}

DeYoung, Hunter and Udell (2004) are defining the village banks based on the division of assets. They think that as long as they meet the assets of less than \$1 billion, the core deposits coming from the relationship financing, providing the traditional financial services with the independent management and operation of banks, etc. with these four conditions, it is the County Community Bank [1].

Berger, Hasan and Klapper (2004) believe that in developed countries, county community banks are domestic banks with assets below $\$ 1$ billion, while in developing countries, county community banks include domestic banks and foreign banks with assets below $\$ 100$ million [2].

\section{2) Domestic research trends}

Kang Shusheng and Zhao Liang (2012) believe that at this stage, it is of great practical significance for our country to support and develop the county community banks that are suitable for the county economic structure. County community banks have certain comparative advantages in financing private small and medium enterprises and agriculture, and have a broader development space [3].

Zhang Shufang (2010) believes that, compared to the existing large commercial banks, some informal financial institutions engaged in financial transactions have contributed more to the local small and medium entrepreneurship and development, and their operating efficiency is higher. Through the establishment of county community banks, it can organize and operate the non-governmental idle funds to make it better in line with the law of market development, and to actively guide the informal financial institutions on the road of normalization and legalization. Although this mode of development is difficult to achieve in the short term, it is of great significance in the long run [4].

Ling Haibo (2017) believes that the strategy of developing county community banking services should be located in small and micro customers, pay attention to the innovation and cross 
selling of bank products, flexible network forms and functions, put emphasis on the integration of business personnel and marketing community, build online and offline Internet platform, and support the innovation of information technology [5].

\section{Content Arrangement}

The first section discusses the background, significance and corresponding domestic and international developments. The second section compares the development status of county community banks at home and abroad. Finally, according to the actual situation of our country, we discuss the development path selections of county community banks in China.

\section{A COMPARATIVE ANALYSIS OF THE DEVELOPMENT MODELS OF COMMUNITY BANKS AT HOME AND ABROAD}

\section{A. The Development Mode and Experience of Foreign Community Banks}

1) From the type of business, the United States "relationship credit" mode.

As we all know, the United States is the birthplace of county community banks, and is also the most mature and most common development of banks. In terms of quantity, after early deregulation, 14078 County community banks have been set up in the United States. At present, it is around 7000.

From the perspective of the development of county community banks, the successful experience of the United States in this area is particularly rich, especially the Wells Fargo Bank. As an important part of the current banking industry in the United States, the Fargo country bank takes the county community bank as its first stage. Even in the present stage, the county community banking business provides more than sixty percent of the funds for the Fargo bank.

2) From the point of view of setting up, the characteristics of the Australian model.

Before and after the 1990, because of the fierce competition in the Australian banking industry, in order to continuously expand the scale of their own development and operation, the banking institutions continued to merge and reorganize, resulting in the chaos of the entire financial order and difficult to regulate. In order to alleviate the deterioration of this situation, the government regulatory authorities have closed down a large number of banking institutions. From 1993 to 1996 in three years, nearly 2000 banks have been closed down, and many areas in Australia have been in a state of financial hollow. However, the needs of the local residents' daily financial services still exist, thus to meet the needs of the residents' financial services and avoid the confusion of the financial order again, the Australian government authorities began to implement the "franchise" policy, and the "franchised County Community Bank" emerged and thrived.

\section{B. Development Model of County Community Banking Institutions in China}

1) Rural County Community Bank mode: Qingdao Jiaonan Hai Hui village bank

Qingdao Jiaonan Hai Hui village bank was formally established in 2008. It is the first village bank with natural shareholders in Shandong. At the same time, it is also the second village bank in Qingdao. In 2008, it was formally established in Jiaonan, Shandong. The Bank of Weifang is the largest shareholder of the bank. After the establishment of the bank, the bank is in conformity with the local market development demand. Rapid development and the establishment of branch branches began in three years. Poli sub bank is the first branch bank established by this bank. In 2013, the Qingdao Banking Regulatory Commission allowed the operation of other branches, indicating that the banks of the Hai Hui village could serve the local economy more deeply.

2) District financial convenience store mode -- Take Minsheng Bank as an example

In the people's livelihood County Community Bank's business aspect, mainly for the deposit business and other bank basic non cash business and so on. As the localization characteristic of the County Community Bank in our country, the County Community Bank of Minsheng Bank adopts the service mode of "self-help + consultation". In general, the service outlets of the county community bank do not involve the related business of cash, mainly with the bank card transaction. At the same time, in order to better meet the location of its financial convenience store, in addition to the above traditional banking business, customers can also carry out the water, electricity and network costs, mobile phone fees and other daily necessities of inquiry and payment through the county community banks; restaurants, cinema reservations and other convenient services are provided too.

\section{3) Intelligent network model is represented by Guang Fa} bank

Another mode is the intelligent network model, which mainly uses intelligent teller machine, the so called "VTM". It is different from Minsheng Bank's "financial convenience store" because it does not need to occupy artificial resources. This type of County Community Bank model doesn't need to set business hours with all weather 24 hours no break work. It can meet the customer's business needs at any time acting as the bank financial housekeeper for the customer around the day. With the continuous development of modern scientific and technological level, many offline business in the banking business opens the online remote operation. The customer can handle the corresponding banking business through the VTM self-service platform, which not only reduces the operating cost of the bank, but also facilitates the customers. As a new model of the development of the County Community Bank, the intelligent network model of the wide development bank has succeeded in getting rid of the time and space limitation of the original banking business, giving customers more and more convenient operation choices and improving the customer's experience satisfaction. 


\section{County Community Bank DeVelopment Path} SELECTION IN CHINA

\section{A. Clarify Bank Network Localization}

At the beginning of the development of our country, the county community banks showed a rapid growth trend in a period of time due to the innovation of ideas and the support of relevant government policies. The scale of the network has exceeded the capacity of the market, and was once stopped by the regulatory agency. When the regulatory agency resumed the business of the County Community Bank, it was hoped that the county community bank could slow down the rapid growth trend before, rationally plan the risk prevention, and develop with the pace suitable for the national economy.

The original intention of the establishment of the county community bank is to provide the local residents with personalized and diversified services and meet the needs of the related financial services in the surrounding small and medium enterprises. The location of the network is for the community, the radiation community and the surrounding area. However, most commercial banks do not take into account the essential characteristics of the county community banks in the county community banking business, but only open the bank outlets to increase the market share by means of the spring wind that support the development of the county community banks by the state, which is obviously contrary to he real will of our country's development of the introduction of the county community banks.

\section{B. Differentiation of Products and Services}

At present, the county community banks should further clarify their own market positioning, as well as integrate into the community as far as possible, and make full use of the surrounding environment, so as to avoid the awkward situation of the County Community Bank branch which is simply just extended to the community. The general commercial banks will carry out standardized and unified management of the subordinate agencies, which has a good effect on improving the efficiency of the banking operation, but it is not suitable for the county community banks. In the construction of county community banks and the development of County Community banking, China's commercial banks can give the county community banks some right of independent transformation. In this way, in the process of operation, the county community banks can adjust their own products and services according to the behavior habits of the community customers and create their own special and brand effects through the detailed investigation and analysis of the target customer groups in the community.

\section{Clearly Positioning the Target Customers}

At present, the county community banks in our country are mainly carried out in the mode of community financial convenience stores. The main service object is the community and the surrounding residents. The characteristics of the county community bank are the convenience services of all kinds of autonomous services and the corresponding inquiry and payment. Although it is convenient for the living of the residents around the community, but for the convenience of the living of the residents around the community, the county and school community banks that we have introduced have lost an important part of the business, i.e. their small and mediumsized enterprises. Although the current county community banks can also carry out a series of loans and other financial services to the surrounding small and medium-sized enterprises, even the approval of the loan procedure, the approval of the loan and settlement business of small enterprises which is similar to that of other banks. But this is the similar to the branch - like institutions. It only expands the bank's classification, increases the approval process, extends the time, and makes the efficiency lower. It does not increase the loan service advantages of the community around the community.

\section{Clearly Positioning Service Target}

Through a brief analysis of the current market consumption selection model, we can realize that the present market is an era of "experiential economy", as well as to the banking service industry. Customer experience satisfaction is increasingly becoming an important indicator for a bank to seize the market, increase customer viscosity and establish customer loyalty, especially in the background of poor product and service homogeneity in the current banking industry. Customer experience satisfaction has gradually become an important factor in customer identification of bank brands. However, at present, most of the banks in China are not deeply aware of the importance of customer experience satisfaction. Even a few banks have begun to consciously improve the quality of service, and most of them stay in standardized service etiquette, and so on. And the customer experience satisfaction we mentioned here should be comprehensive and multifaceted. Service etiquette should be included, but not only that, but also involves financial products, customer activities and so on. Obviously, China's commercial banks, including County community banks, have many deficiencies in this respect, and the satisfaction level of customers is not high.

\section{CONCLUSION}

This article is mainly aimed at our country. Although there are many banking and banking services in our country, but the types of financial services and the lack of diversity are serious problems. It is obviously not able to meet the diversified needs of the regional economic closed circles in the different economic development stages of our country. Because of this, how to rationalize the structure of the current financial institutions in China and make it more effective to adapt to the current situation of our country's economic development is the key to the problem to be solved in our country.

From the case of the successful practice of the county community banks at home and abroad, the county community bank is different from the market positioning of the large commercial banks which makes it more effectively targeted to provide personalized custom service to its target customer groups and meet the special needs of the financial services. From the comparison of the different academic research reports on financial development at home and abroad, it is concluded that a sound and perfect financial system should include large commercial banks, small and medium banks and all kinds of banking financial institutions. Only by their common and 
balanced development can they enrich the whole financial system and reduce systemic financial risks.

\section{REFERENCES}

[1] Robert DeYoung, William C. Hunter, Gregory F. Udell. The Past, Present, and Probable Future for Community Banks [J]. Journal of Financial Services Research ,2004 (2):100-103.

[2] Allen N. Berger, Iftekhar Hasan, Leora F. Klapper. Further Evidence on the Link between Finance and Growth: An International Analysis of Community Banking and Economic Performance.[J]. Journal of Financial Services Research, 2004 (2):123-125.
[3] Kang scholar, Zhao Liang. The choice and optimization of the development path of the County Community Bank -- comparison with the foreign county community banking system in the United States and other countries [J]. The bulletin of Hebei University of Economics and Business, 2012,33 (02): 71-74(In Chinese).

[4] Zhang Shufang. Analysis of China's development of County Community Bank's thinking and Countermeasures [J]. Shopping malls modernization, 2010 (5): 100-102(In Chinese).

[5] Ling Hai Bo. Theory and strategy of County Community Bank Development [J]. Contemporary economy, 2017 (10): 64-66(In Chinese). 